\title{
Robot laser hardening and the problem of overlapping laser beam
}

\author{
Babic, M. ${ }^{a}{ }^{\text {, }}$, Balic, J. ${ }^{b}$, Milfelner, M. ${ }^{c}$, Belic, I. ${ }^{d}$, Kokol, P. ${ }^{e}$, Zorman, M. ${ }^{f}$, Panjan, P. ${ }^{g}$ \\ ${ }^{a}$ EMO orodjarna d.o.o., Bezigrajska 10, 3000 Celje, Slovenia, EU \\ ${ }^{\mathrm{b}}$ Faculty of Mechanical Engineering, University of Maribor, Smetanova 17, 2000 Maribor, Slovenia, EU \\ 'Tic-lens d.o.o., Bezigrajska 10, 3000 Celje, Slovenia, EU \\ dinstitute of Materials and Technology, Slovenia, EU \\ e Faculty of Health Sciences, University of Maribor, Zitna 15, 2000 Maribor, Slovenia, EU \\ ${ }^{f}$ Faculty of Electrical Engineering and Computer Science, University of Maribor, Smetanova 17, 2000 Maribor, Slovenia, EU \\ gJozef Stefan Institute, Jamova 39, 1000 Ljubljana, Slovenia, EU
}

\section{A B S T R A C T}

Since 1970, many studies of various laser machining processes and their applications have been published. This paper describes some of our experience in laser surface remelting, consolidating, and hardening of steels. We focus on the problem of robot laser hardening of metals with overlapping of the hardened zone. The process of laser hardening with remelting of the surface layer allows us to very accurately determine the depth of modified layers. In this procedure, we know the exact energy input into the material. Heating above the melting temperature and then rapidly cooling causes microstructural changes in materials, which affect the increase in hardness. We identify the relationship between hardness and width of overlapping. We describe the results of previous work, research, and experience in robot laser hardening of metals. We also show the results of laser processing techniques with the problem of overlapping. Our tests were carried out on materials of DIN standard 1.2379 and 1.7225 , and measurements were performed in the hardened zone of overlapping at $2 \mathrm{~mm}, 3 \mathrm{~mm}, 4 \mathrm{~mm}, 6 \mathrm{~mm}$, and $10 \mathrm{~mm}$. We show relationship between hardness and width of overlap for material of DIN standard 1.2379 and 1.7225. The modeling of the relationship was obtained by the 3 layers artificial neural network.
\end{abstract}

\section{ARTICLE INFO}

Keywords:

Robot

Laser

Hardening

Overlapping

Neural network

*Corresponding author: babicster@gmail.com (Babic, M.)

\section{References}

[1] Totten, G. E. (2006). PhD. Fasm, Steel heat treatment, second edition.

[2] Xu, Z., Leong, K. H., Reed, C. B. (2008). Nondestructive evaluation and real-time monitoring of laser surface hardening, Journal of Materials Processing Technology, Vol. 206, No. 1-3, 120-125.

[3] Kennedy, E., Byrne, G., Collins, D. N. (2004). A review of the use of high power diode lasers in surface hardening, Journal of Materials Processing Technology, Vol. 155-156, 1855-1860.

[4] Ion, J. C. (2005). Laser processing of Engineering Material-Principles, procedures and industrial applications, Elsevier, 2005.

[5] Ganeev, R. A. (2002). Low power laser hardening of steels, Journal of Materials Processing Technology, Vol. 121, No. 2-3, 414-419.

[6] Pashby, I. R., Barnes, S., Bryden, B. G. (2003). Surface hardening of steel using a high power diode laser, Journal of Materials Processing Technology, Vol. 139, No. 1-3, 585-588.

[7] Patil, S. B. (2007). Surface treatment using laser heat source, PhD Thesis, Swami Ramanand Teerth Marathwada University, Vishnupuri, Nanded. 
[8] Kramar, D. (2009). High-pressure cooling assistance in machining of hard-to-machine materials, PhD Thesis, Faculty of Mechanical Engineering, Ljubljana, Slovenia.

[9] Babic, M., Stepišnik, S., Milfelner, M., Babič, S. (2011). Point robot laser hardening. In: Perme, T., Svetak, D. (ed.), Industrijski forum IRT, Portoroz, junij 2011. Vir znanja in izkušenj za stroko: zbornikforuma. Skofljica, 31-34.

[10] Babic, M. Robot laser hardening with different angels on different materials. In: Godec, M. (ed.), (2011). 19th Conference on Materials and Technology, Portoroz, Slovenia. Program and book of abstracts. Institute of materials and technology, Ljubljana.

[11] Babic, M. (2010). Optimal parameters of robot laser cell for hardening with different angles. In: Zajc, B. (ed.), Trost, A. (ed.). Proceeding of the Nineteen International Electrotechnical and Computer Conference ERK 2010, Portoroz, Slovenia, (Proceedings Electrotehnical and Computer conference ERK). IEEE Region 8, Slovenian section IEEE, 219-222.

[12] Tikk, D., Kóczy, L. T., Gedeon, T. D. (2003). A survey on universal approximation and its limits in soft computing techniques, International Journal of Approximate Reasoning. Vol. 33, No. 2, 185-202.

[13] ElHefnawi, M., Mysara, M. (2012). Recurrent Neural Networks and Soft Computing, Intech, Rijeka. 